\title{
Digital Curation and Information Design in digital environments: women's museums panorama
}

\author{
Curadoria Digital e Design da Informação em ambientes \\ digitais: panorama em museus do feminino
}

\author{
Maria José Vicentini JORENTE1 (D) 0000-0002-0492-0918 \\ Stephanie Cerqueira SILVA' 1 (D) 0000-0001-7533-496X \\ Mariana Cantisani PADUA' (iD) 0000-0003-1245-3608
}

\begin{abstract}
Women's museums take on significant functions for social discussions which, through preservation and access to the memory and culture of their collections, provide new habits and perspectives on objects constituted by structures of multiple languages on the Web. In this perspective, this study aims to understand how Digital Curation and Information Design in Information Science contribute to information presentation, access and sharing in these digital environments on the Web. The general objective was to contextualize the concepts and definitions of Digital Curation and Information Design to identify possible articulations for information organization and its presentation of women's museums digital collections. The study is qualitative in nature and descriptive-exploratory. It consisted of a bibliographic review of the themes correlated with data collection in the scope of collections and digital environments of women's museums, through information from the International Association of Women's Museums and Patrimonio en Femenino. The results showed a low number of digital collections available and also the need for reflection on the methodology of planning and creating digital environments as a laboratorial process, continuous, in perpetual beta, iterative and in successive improvements. The study concluded that other dimensions of women's memory preservation should be constituted to facilitate information access and sharing with the implementation of Digital Curation and Information Design resources for the construction of environments and, in them, their collections.
\end{abstract}

Keywords: Digital curation. Digital museums. Genre. Information design. Women's museums.

\section{Resumo}

Os museus do feminino assumem funções significativas para as discussões sociais que, por meio da preservação e do acesso à memória e à cultura de seus acervos, proporcionam novos hábitos e olhares aos objetos constituídos por estruturas de múltiplas linguagens na Web. Nesse sentido, busca-se entender como a Curadoria Digital e o Design da Informação na Ciência da Informação trazem contribuições para a apresentação, o acesso e o compartilhamento da informação nesses ambientes digitais. O objetivo geral foi contextualizar os conceitos e definições de Curadoria Digital e Design da Informação a fim de identificar possíveis articulações para a organização e apresentação da informação em acervos digitais de museus do feminino. O estudo é de natureza qualitativa, do tipo

1 Universidade Estadual Paulista "Júlio de Mesquita Filho", Departamento de Ciência da Informação, Faculdade de Filosofia e Ciências. Av. Hygino Muzzi Filho, 737, Mirante, 17525-900, Marilia, SP, Brasil. Correspondência para/Correspondence to: M. J. V. JORENTE. E-mail: <mj.jorente@unesp.br>.

Apoio/Support: Coordenação de Aperfeiçoamento de Pessoal de Nível Superior (Financing Code 001 and with resources from Public Notice - Edital no 01/2021).

Received on March 18, 2021, final version resubmitted on August 2, 2021 and approved on September 13, 2021.

Como citar este artigo/How to cite this article

Jorente, M. J. V.; Silva, S. C.; Padua, M. C. Digital Curation and Information Design in digital environments: women's museums panorama. Transinformação, v. 33, e210013, 2021. https://doi.org/10.1590/2318-0889202133e210013 
descritivo-exploratório e consistiu no levantamento bibliográfico das temáticas, correlacionado com as coletas de dados no âmbito dos acervos e ambientes digitais dos museus do feminino por meio de informações da International Association of Women's Museums e do Patrimonio en Femenino. Os resultados demonstraram um número baixo de acervos digitais disponibilizados e, também, a necessidade de uma reflexão sobre a metodologia do planejamento e da criação de ambientes digitais como um processo laboratorial, contínuo, em beta perpétuo, iterativo e em sucessivo aprimoramento. Considera-se que outras dimensões da preservação da memória da mulher podem ser constituídas para viabilizar o acesso e o compartilhamento da informação com a implementação dos recursos da Curadoria Digital e do Design da Informação para construção de ambientes digitais e, neles, de seus acervos.

Palavras-chave: Curadoria digital. Museus digitais. Gênero. Design da informação. Museu do feminino.

\section{Introduction}

The impact of Information and Communication Technologies (ICT) on daily life has generated constant changes in the way subjects relate to information and, consequently, has expanded the forms of interaction. Such expansion creates new challenges for academic studies and allows exploration and reflection from new perspectives.

The narratives displayed on the World Wide Web (Web) in general and, more specifically, those related to memory and culture, demand treatment which contemplate the complexity of digital environments, information systems, information subjects, stakeholders, communities of interest and other parties involved in the communication processes. When featured on the Web, information related to culture and memory boost relationships in different contexts and new emergencies come up. Among the emergencies are the new possibilities for information access and sharing to be experienced in the scientific, cultural and social spheres.

The Web, in the first half of the $21^{\text {st }}$ century, has also allowed extensive information sharing of what is stored there. Archives, libraries and museums, traditional ones or those where collections are made available on the Web, are institutions made up of different types and themes; they are cultural, informational and social, and one of their responsibility is to ensure that the community of interest has access to information regardless of the medium.

In the context of museums, spaces made up of material and / or immaterial collections created to safeguard, preserve and give access to memory, the narratives are constructed guided by cultural and social circumstances, and made viable by implied contracts between institutions and the communities of interest to which they are targeted.

Museums that have collections exhibited in some way on the Web communicate information and propose forms of information access and sharing, a fundamental factor in today's digital world. The environments for providing information and digital collections support new habits and perspectives for representations and presentations of informational content and formats that take on structures made up of multiple languages.

It is important to highlight that, currently, the functions attributed to museums go beyond the preservation of collections and memories. In the case of collections and museums focused on gender issues, such as women's museums, they assume a significant role in social discussions, as they seek to rescue women's memory and heritage and give visibility to their active participation in social, political, cultural and daily life, both in the past and in the present (Vaquinhas, 2014).

In this sense, exhibiting collections, traditional or digital ones, that present the theme of women favors their visibility and expands the possibilities of building a feminine protagonism in different social practices. Regardless of the themes in women's museums, identified by Vaquinhas (2014) as Women's History, Women's Rights and Art museums, they all work with image representations of paintings, photographs, sculptures, among other artifacts, as a language resource.

In digital environments, the work results in language convergences that determine a need for organization so that their presentation is in accordance with the purposes of these museums, and give rise to expressions and 
strengthening ideas for these communities. The relationships of perception, motivations and expectations of the visitor to these digital environments need to address functional and educational content and information. The structures and attributes of the Web as a communication channel allow to adapt the content of the websites to facilitate access and retrieval of cultural heritage information.

Digital Curation (DC) converged with Information Design (ID) in Information Science (IS) may contribute to the effectiveness in the creation of these digital environments with functional proposals, both for their presentation, access and sharing and for information management. In this context, the general objective of the article is to contextualize concepts and definitions of DC and ID to identify possible articulations for information organization and its presentation in digital collections in women's museums.

Based on the three areas of knowledge, the conducted studies demonstrated the need for reflection on the methodology for planning and creating digital environments as a laboratorial process, continuous, iterative in perpetual beta, and in constant improvement. These informational spaces should be in constant maintenance and support, given the complexity of the environments designed for community watch and participation. In this way, continuous improvements in information access and sharing are allowed so that the environment is efficient, effective and reaches informational subjects. Restructured from parameters obtained from the activities carried out by the community of interest, the digital environments result in uninterrupted practices and technical adaptations by information professionals.

This study considers that the implementation of DC and ID resources for the construction of digital environments and, in them, the digital collections, contribute for the women's museums to expand their objectives through collaborative activities developed in the Web and with the use ICT. Other dimensions for the preservation of women's memory can be constituted to facilitate information access and sharing and, thus, can promote greater participation in the search for foundations to discuss social issues in contemporary times.

\section{Methodological Procedures}

The research resulted from this study is of qualitative nature based on the descriptive-exploratory type. The qualitative approach was chosen as it is characterized as transdisciplinary, present mainly in the human and social sciences, which analyzes the specificities of concrete cases of activities and experiences in certain contexts (Chizzotti, 2003; Flick, 2009). The research is descriptive-exploratory in that it provides a dialogue between the theoretical foundation and the analysis of the situation, in order to identify relationships, problems and possible solutions from a general overview (Gil, 2008; Triviños, 1987). Thus, it consists of an investigation linked to the literature review and knowledge acquisition about the object of study.

The bibliographic review was directed towards the treatment of the relationships between DC, ID and IS. The authors chosen for the theoretical foundation are consolidated in their areas of expertise and have constantly conceptualized our research. For the DC, articles by pioneering authors in the field such as Sarah Higgins and Daisy Abbott, and others institutionally attributed to the Digital Curation Centre (DCC) were studied. As for ID, classic authors such as Robert Horn and Jorge Frascara were the basis of the review. In the national panorama, the review of the theme and the intersection of the areas previously listed with the IS respected the ten-year time interval of publication in books, journals and conferences in the area.

Data collection, the exploratory phase of the research, carried out in January 2021, took place in the context of women's collections and museums and on their digital environments. A first data collection was carried out on the list (dated October 2019) which globally accounts for women's initiatives and museums, made available by the International Association of Women's Museums (IAWM). Three categories of information were extracted from the list: (1) the number of initiatives, brick-and-mortar museums and non-brick-and-mortar museums, per continent; 
(2) the number of digital environments in operation; (3) the number of available digital collections. Afterwards, in the catalogs made available by Patrimonio en Femenino, information on the number of objects and the subjects covered between the years 2011 and 2016 were explored.

It is noteworthy that the sequence of the narrated methodological actions required individualized procedures, given the heterogeneity of the design and structure of each digital environment and each catalog, which were analyzed with respect to their specificities. Finally, the systematization of information was carried out with the Excel $^{\circledR}$ software. Such information was correlated with the methodologies, strategies and practices of the $D C$ and the ID, from the perspective of Information Science, in order to expand proposals for accessing and sharing digital collections with themes relevant to the stakeholders.

\section{Convergences between Digital Curation and Information Design in Information Science}

Dialogically, the articulation of languages, technologies and humanities benefits communication across systems and interoperability, and provides opportunities for the convergence of CD actions with ID, which cooperate in the area of IS. Both DC and ID are fields of investigation working based on potentializing methods and strategies for information organization and its presentation on digital environments. This section explores DC and ID resources which, converged, contribute to subjects' interaction and participation through information access and sharing.

Digital Curation emerged in the late 1990s, at a time of concern with digital preservation due to the continuous growth of digital information and the expansion of the internet and ICT (Beagrie, 2004; Higgins, 2011). Digital Curation has evolved from the perception of the need for digital object treatment given the rapid technological obsolescence. Since its creation, DC has presented actions for the management of digital objects especially related to digital storage and preservation processes to provide long-term access and also add value (Beagrie, 2004).

At the same time, in order to solve challenges surrounding DC, research initiatives have emerged, such as the DCC, a research center founded in 2004, which considers the effective development of DC as a collective effort between institutions from new disciplines (Digital Curation Centre, 2020a).

Thus, DC has played a comprehensive role in the process of managing digital objects throughout their life cycle: "[...] [DC] reduces threats to their long-term research value and mitigates the risk of digital obsolescence" (Digital Curation Centre, 2020b, online). Digital Curation is applicable in different management activities of digital objects such as planning, creation, digitization and documentation practices, in addition to the future availability of access and reuse (Abbott, 2008).

According to Abbott (2008), there are short- and long-term advantages in implementing DC. In the short term, the benefits are in improving digital objects quality, using common standards, verifying authenticity, formally recording, exploiting the initial investment in the best way and speeding up information access and sharing (Abbott, 2008). In the long term, the advantages refer to preserving and protecting digital objects from loss and obsolescence, allowing continuous access and encouraging reuse, providing information about the context and provenance, ensuring that they remain significant and, finally, creating infrastructure for management aimed at preservation and sharing (Abbott, 2008).

The described advantages depend on the DC effectiveness, in which the preparation of implementation planning is an essential step. For this, the Digital Curation Lifecycle Model (DCLM), developed by Higgins and used by DCC, is a planning tool that adapts to different situations and allows the identification of the best activities for DC application (Higgins, 2008), considering that the lifecycle consists of continuous processes that require attention and investment (Digital Curation Centre, 2020b). 
The DCLM ensures that all the necessary phases are identified and planned so that the full lifecycle actions are implemented in the correct sequence (Higgins, 2008). The model (Figure 1) presents the DC phases divided into blocks of: full lifecycle actions, sequential actions and occasional actions.

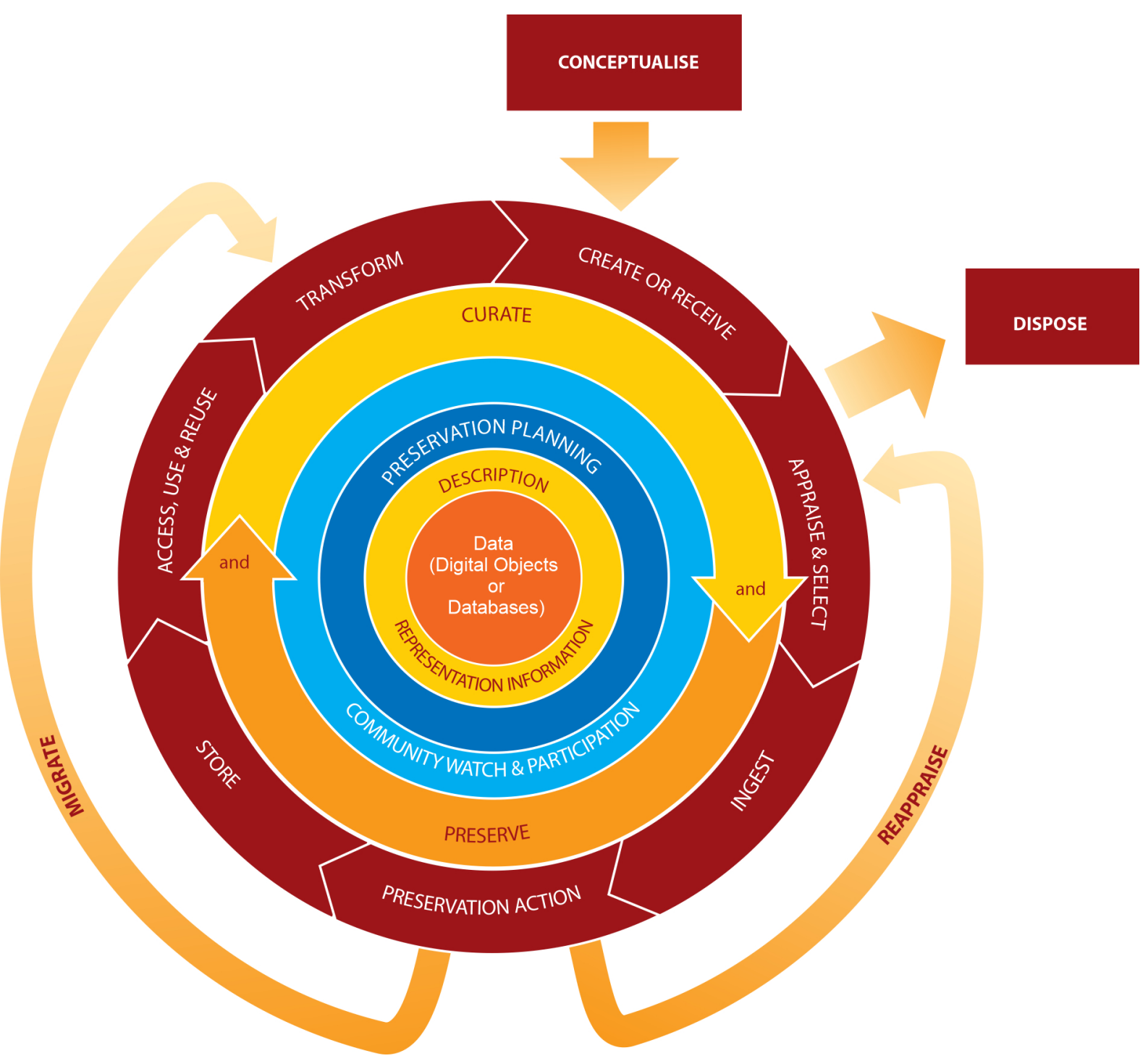

Figure 1 - Digital Curation Lifecycle Model. Source: Higgins (2008).

The full lifecycle actions block is at the center of the model and consists of: description and representation information; preservation planning; community watch and participation; curate and preserve. These are interrelated actions, guided for the development of the entire DCLM, such as metadata assignment, planning, watch (observation) and checking of curatorial and preservation activities (Higgins, 2008).

The sequential actions are: conceptualize; create and receive; appraise and select; ingest; preservation action; store; access, use and reuse; transform. They are interconnected and following the sequence is decisive for 
an efficient and effective DC, even if, according to the inserted contexts, not all are identified as necessary (Higgins, 2008).

Finally, occasional actions consist of: dispose; reappraise and migrate. They take place in specific periods and situations defined by policies, legislation, validation failures and the need for format modifications (Higgins, 2008).

Sabharwal (2015) exemplifies each DCLM action from the perspective of Archives, Libraries and Museums, and concludes that the model has useful resources for the conceptualization, implementation and appraisal of digital information. For the author, conceptualization is the most important and necessary action before implementing the DCLM, as it requires execution according to each organizational structure and with types of collections and interests, as they are variables that directly impact on action planning (Sabharwal, 2015).

In this perspective, the outline of this study highlights the following actions: community watch and participation (described in the light blue band of Figure 1), access, use and reuse, in this study named information access and sharing (described in the red band of Figure 1) and description and representation information (described in the yellow band of Figure 1). It is essential to highlight that the community watch and participation action is a two-way path which may refer both to the professionals - the community behind the system - and to the subjects who will have access to that information.

Therefore, the emphasis is given to informational subjects and the community of interest for three reasons: preparing the information to make it efficient and effective to meet the contextual needs of the subjects; establishing direct communication with sending items, comments and suggestions from the community to the curator (Sabharwal, 2015); and making the custodied information follow a flow of circulation and reach the subjects regardless of the support or medium (Araújo, 2018).

Digital Curation articulated to the IS area becomes a resource for action planning and management to approach stakeholders and community of interest. Its interdisciplinarity in the area is increasing and proves to be essential for collaborating with theories and practices related to digital objects' selection, maintenance and preservation processes, which favor scientific, cultural and memory activities, in addition to the concern with information in its various aspects, moments and instances (Araújo, 2018).

Information Science is an interdisciplinary area, situated as a human and social science (Araújo, 2018). Its confluence with other areas offers improvements in personal and institutional communication efforts. Nakano (2019) highlights converging points among DC, IS and ID: information, message communication, storage, retrieval, and information access for information transmission and knowledge construction. Such points demonstrate that interdisciplinarity raises perceptions of properties for improvements during the communicational process supported by the information organization and its presentation, especially by language and system interoperability offered on the Web.

The evolution of the fields and their maturity corroborates to claim that the convergence points and the interdisciplinary nature of IS and DC also lack a multidisciplinary team. Bringing together scholars, librarians, archivists, designers and information technologists to produce solutions that would not be possible without the perspectives and skills from these professionals has become necessary and imperative.

Information Design (ID) is a multidimensional subarea of Design that plans and produces informational discourses through methods and strategies that enhance interactions (Jorente, 2015). Interdisciplinary to IS, ID is an active ally in the information representation process to make a message clear beyond the aesthetic function, as ID is related to content, language and information form to solve problems derived from the complexity of systems (Oliveira; Jorente, 2019).

With a human-centered focus, the objective of ID is to create effective communication capable of facilitating the "processes of perception, reading, comprehension, memorization and use of the information presented" 
(Frascara, 2015, p. 5). In view of the varied possibilities of converging languages in the Web environment, studies are needed to make this process satisfactory.

Horn (1999) considers that a new language for communication emerged from technological potentialities, the so-called visual language: you cannot remove words, images or shapes from a visual language without destroying or radically diminishing the meaning the reader can obtain (Horn, 1999). Thus, to project high quality information, some attributes are necessary. Information has to be accessible (easily available), appropriate for its content and for those who will access it; it has to be attractive, reliable, complete, concise, interpretable, objective, relevant (connected to its purpose) and, above all, usable (Frascara, 2015; International Institute for Information, 2007).

To meet this objective, Frascara (2015) points out that ID process involves two moments: information organization, which comprises the content and its meanings, texts and images; and planning and implementing visual presentation. Knowledge beyond the types of languages, symbols, texts and images are demanded; it is necessary to understand the cognitive processes (Frascara, 2015), understand how subjects can move through the content during interaction processes, and, therefore, knowledge regarding human behavior is required (Jorente; Padua; Nakano, 2019).

The processes for constructing information, a system and/or a digital environment involve multidisciplinary characteristics and, in addition to technological resources, resources from human relations must be incorporated to ensure successful information access and sharing for subjects. In this sense, information organization and its presentation are a complex process requiring knowledge on languages, technologies and humanities for planning and execution aiming at interoperability.

Interoperability is a communicational process across systems resulting from the improvement of the capacity exercised by each of them without generating dependence on each other (Jorente; Padua; Nakano, 2019). Conversely, dialogical relationships are related to human interactions prior to the choice of technological support. Norms, standards, policies and institutional objectives must be part of the requirements for planning to ensure efficiency and effectiveness in the intercommunication and technical, semantic and organizational complementation (Jorente; Padua; Nakano, 2019).

Thus, the mere information availability is not enough, in the same way that the digital object should not be seen in isolation or only in the field of digital preservation. Building a satisfactory relationship among museums, collections and digital environments and the community of interest is precisely to understand the potential offered by all the elements that are part of this system. Therefore, they are influencing factors for information access and sharing of collections and, in this way, they expand the discussions and warrant the social function of these spaces.

\section{Representations of women in digital environments}

The role played by culture and information institutions fosters essential debates that contribute to the expansion of visibility, empowerment of minority groups, the development of public policy projects and practices, among other opportunities arising from their actions. The gender-related issues, in this sense, are important and increasing agendas, in which the actions of memory preservation and access can provoke and provide subsidies to necessary dialogues. In this view, initiatives that address women become indispensable for the representation and representativeness of women and, in addition, act as a basis for confrontations arising from social struggles.

Women's Museums are cultural institutions that can significantly cooperate with women's narratives with new perspectives on the creation, access and sharing of their collections.

[...] women's and/or gender museums are opening new paths both in the specifically historiographical field and in the survey of issues that help to understand the way women have shaped their lives and have articulated (and articulate) them with social changes (Vaquinhas, 2014, p. 10, our translation). 
The IAWM is an example of a project aiming at preserving women's memory through cooperation between institutions that treat women and/or gender around the world (International Association of Women's Museums, 2020). It was set in 2008 by the establishment of the network women in museum and was transformed into an association in 2012, with administrative headquarters in Merano, Italy (International Association of Women's Museums, 2020). International Association of Women's Museums offers three services to its members: monitoring associated museums - through a database - to promote and publicize activities and exhibitions via official channels; working internationally in a network to organize conferences, discussions and exchanges with members and with other networks; cooperating with other museums to create collaborative projects (International Association of Women's Museums, 2020).

For International Association of Women's Museums (2020), women's museums seek their own spaces aimed at education, training and encouraging women's self-confidence when working to raise awareness through actions and tools aligned with their objectives. Altogether, 140 initiatives (projects) and women's museums are counted, including traditional and virtual members of the Association around the world. The data in Figure 2 shows the number of traditional and virtual museums and initiatives per continent and the country with the largest number of projects.

The global performance of women's museums is significant and fundamental for memory preservation, as well as for information exchange and collaborations among them. On the other hand, two points are highlighted: North America and Europe account for approximately $60 \%$ of the globe, with North America showing the

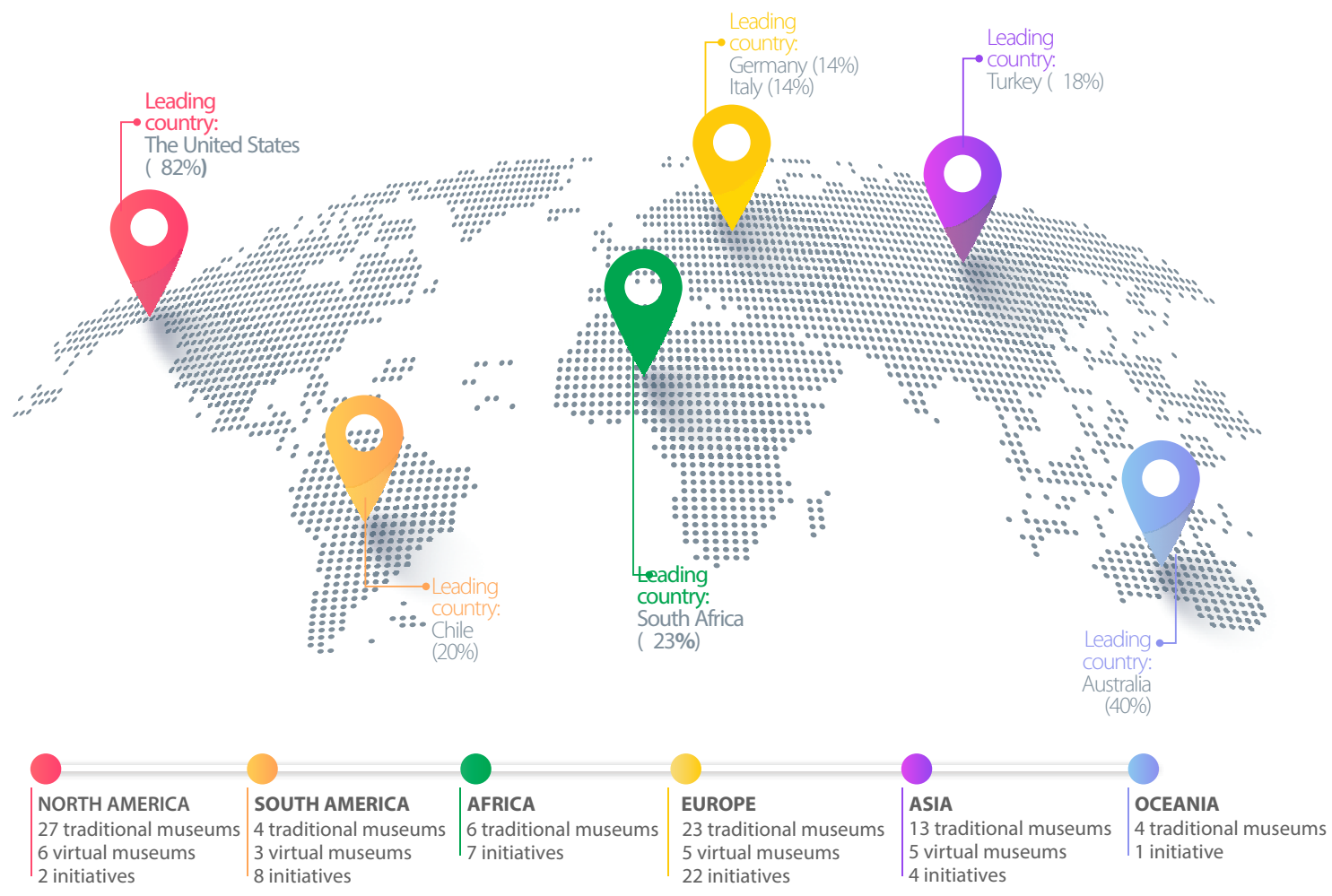

Figure 2 - Women's initiatives and museums around the world. 
predominance of the United States; South America, in the published list, mistakenly encompasses the countries of Central America. Given the misunderstanding, the real number for South America falls to four traditional brick-andmortar museums, one virtual museum and four initiatives.

The IAWM classifies 19 museums as virtual, probably due to the absence of a traditional brick-and-mortar building. It is noteworthy, however, that digital environments totalize 125, of which 42 have digital collections; that is, some museums constitute the two modalities. Thus, although the concentration of museums is in certain countries and there is a shortage of them in others, the verification of digital collections facilitates their access and integration.

Another initiative is Patrimonio en femenino, in Spain, created from a project in 2010 with the purpose of gathering, in a digital catalog, collections held by museums that "[...] would allow to outline visions of the feminine presence from different angles, contextualizing their protagonism in the most diverse civilizations and from the origins of humanity to the present day" (Garrido; Gómez, 2016, p. 82, our translation).

Altogether, six catalogs were built, consisting of representations of paintings, sculptures, photographs, clothing, furniture, among others, with central themes that unfold in sections and subsections (Table 1).

The items that make up the catalogs are from different Spanish museums, except for the last one, which, due to the partnership with Ibermuseums, also added items from the collections of Argentina, Brazil, Chile, Colombia, Mexico, Portugal and Uruguay (Garrido; Gómez, 2016), which diversified and expanded the digital collection. The set of catalogs and the social themes demonstrate how vast the possibilities of converging representations of women are.

In the Brazilian context, the country has only one initiative listed by the IAWM since 2010, the Museu da Mulher Brasileira, in Belém, state of Pará. However, in a parallel search on the Web, two digital environments were identified with publications referring only to that association dated back from 2010, and a document that honored a member of the initiative in 2017 (Pará, 2017).

Brazil has greater participation in the Patrimonio en femenino environment, with a total of 15 items from the Brazilian collection made available by: Casa de Margarida Maria Alves Museum (João Pessoa/PB), Museum of the Republic (Rio de Janeiro/RJ), Archeology and Ethnology Museum, University of São Paulo (São Paulo/SP), Museum of the Northeast Man (Recife/PE), National Museum of Fine Arts (Rio de Janeiro/RJ) and also by Instituto Itaú Cultural (São Paulo/SP).

In addition to these cases, the most recent scenario referring to Brazil and the women's museum is at the Museu Internacional da Mulher - Associação (MIMA, International Women's Museum - Association), from Portugal, opened in 2016, with its first exhibition in November 2019 (International Association of Women's Museums, 2018). It is the only member museum of the Portuguese-speaking IAWM (International Association of Women's Museums, 2018) and, for this reason, its objective focuses on Portuguese-speaking countries. It consists of artistic expressions of feminine representation, in addition to those found in museums of fine arts and/or contemporary art, but with the intention of covering other manifestations, as reported by Canton, Brazilian curator of the museum (RFI convida..., 2019).

Such positions highlight, both the delay and the lack of projects that are so necessary for the country:

Increasing knowledge about our history, searching for instruments and ways to preserve our cultural expressions ventures us to reflect on images, myths and symbols about women, about femininity. The construction of such images, by art or science, shapes our place as women. For this reason, to recover the presence of women in history is to rethink the assigned place and often to resize the symbols and myths shaped by a culture of inequality (Godinho, 2016, p. 41, our translation). 
Table 1 - Themes that make up the Patrimonio en Femenino catalog.

\begin{tabular}{|c|c|c|c|}
\hline Main Theme & Sections & Subsections & Number of items \\
\hline \multirow[t]{15}{*}{ Women's heritage (2011) } & Works carried out by women & - & 35 \\
\hline & \multirow[t]{7}{*}{ Discourses and models of femininity } & Symbolic Power & 19 \\
\hline & & Social prestige and lineage & 27 \\
\hline & & Maternity models & 9 \\
\hline & & Matrimony & 16 \\
\hline & & Association with the household & 11 \\
\hline & & Discourses about women's body & 14 \\
\hline & & Discrimination and misogyny & 8 \\
\hline & \multirow[t]{5}{*}{ Women's work and knowledge } & Cultural Production & 22 \\
\hline & & Education & 19 \\
\hline & & $\begin{array}{l}\text { Procurement, production and } \\
\text { distribution of goods }\end{array}$ & 15 \\
\hline & & Care, health and hygiene & 6 \\
\hline & & Political activity & 12 \\
\hline & Breaks and transgressions & - & 26 \\
\hline & Perpetuate memory & - & 10 \\
\hline \multirow{5}{*}{$\begin{array}{l}\text { Absences and Silences } \\
\text { (2012) }\end{array}$} & Authority and power & - & 15 \\
\hline & Science and education & - & 14 \\
\hline & Creation and exhibition & - & 17 \\
\hline & Work and labor & - & 15 \\
\hline & Rights and equity & - & 7 \\
\hline \multirow{5}{*}{$\begin{array}{l}\text { Women in adversity: } \\
\text { times and setbacks (2013) }\end{array}$} & Social change & - & 26 \\
\hline & Subsistence and survival & - & 19 \\
\hline & Political conflicts and transformations & - & 20 \\
\hline & Personal territory & - & 25 \\
\hline & First names & - & 18 \\
\hline \multirow{5}{*}{$\begin{array}{l}\text { Tradition and modernity } \\
\text { (2014) }\end{array}$} & Faithful to tradition & - & 44 \\
\hline & The difficult conquest of modernity & - & 25 \\
\hline & Until the end & - & 19 \\
\hline & Roundtrip paths & - & 23 \\
\hline & First-person & - & 10 \\
\hline \multirow{8}{*}{$\begin{array}{l}\text { Eros and Anteros: views } \\
\text { on female sexuality } \\
\text { (2015) }\end{array}$} & Eros and Anteros & - & 22 \\
\hline & Unconfessable secrets & - & 9 \\
\hline & From Eva to la femme fatale: archetypes & - & 20 \\
\hline & Otherness images & - & 9 \\
\hline & Living sexuality & - & 36 \\
\hline & The construction of eroticism & - & 15 \\
\hline & Curious eyes & - & 17 \\
\hline & The woman object & - & 23 \\
\hline \multirow[t]{4}{*}{ Women's memory (2016) } & Women and identity: community and interculturality & - & 41 \\
\hline & Rights and equity & - & 54 \\
\hline & Symbols and myths around genre & - & 48 \\
\hline & Heritage's territory & - & 19 \\
\hline
\end{tabular}

Source: Prepared by the author (2021).

Note: data collected from the website Patrimonio en Femenino (2020) in January, 2021. 
When listing and comparing the initiatives from the perspective of DC and ID in the Web context, this is considered to be a conducive space to expand and enhance the insertion of its collections and to foster dialogue both between women's museums and for the relationship with the community of interest. The number of museums that have digital environments is significant as the use of the internet facilitated by ICT is increasing access to them. In this sense, the resources offered by the convergence of DC and ID are essential to be implemented in such practices to make information mediated by the organization and presentation functional.

\section{Curation actions in women's museums digital environments from the perspective of Information Design}

The creation of digital environments guided by the actions of community watch and participation, of description and representation information in addition to information access and sharing proposed by DC, together with the human-centered ID resources, allow the planning of information organization and visual practices to be optimized to promote interaction within the communicational process. Museums' digital environments must be understood as part of the structure of communication and relationship with the community, and the potential offered by ICT can be adopted as a means to make their items available through multiple languages and different supports resulting in integration and in interactivity for internauts (Padua; Jorente; Semedo, 2019).

Even though the feminine museum institutions, both in brick-and-mortar and virtual museums, work with specific themes, information scalability on the Web allow potential groups to open up beyond the communities of interest. In this way, community watch and participation is a method that helps technical processes - such as information representation and organization - until information creation and presentation as form and content. Although the flexibility the Web brings to information search does not follow hierarchical standards based on library practice, allowing collective activity in new interpretations, classifications, categorizations to understand the community perception is a resource that has been discussed in the IS literature in the post-custodial paradigm.

In the same line, the authors Jorente, Padua and Nakano (2019) state that the DC role in the Semantic Social Web results in improvements in convergences across media and associated environments for information access and sharing when informational subjects and communities of interest interact in the constitution of memories.

Semantic Social Web is the one that has characteristics of dynamics, interaction, collaboration, interoperability and language convergence. From the Semantic Web, it brings system interaction, and the possibilities created by interoperability that converges languages; from the Social Web, it brings the dynamics and the collaborative construction that occurs in the interactions among subjects, their specific contexts and their different cultures (Jorente; Padua; Nakano, 2019, p. 53, our translation).

The availability of museum collections in a digital environment, according to Sayão (2016), amplifies physical collections and generates new presentations, contextualization and interpretations based on the objects. Sayão (2016) points out that such action oriented to issues of information access and sharing is manifested in the DC planning with possibilities of adding content, languages and materials; obtaining a collaborative space and cooperating for education and scientific research.

The described DC actions have a double result when reflecting on the possible application techniques in these spaces and, also, of establishing a promising relationship with the community. However, for such results to occur effectively, the interface and the presented information construction must be rethought so that they offer visual and informational connections and the internaut can deepen their research within a digital collection (Padua; Jorente; Semedo, 2019).

Portugal (2020) infers that ID becomes an intellectual method when used to represent and frame knowledge issues. Through conceptualizations, instruments and methodologies, ID acts as a practice based on problem 
solutions accomplished by the convergence of languages, systems and hybridity among them, in an attempt to present improvements in interoperability beyond technologies, that is, for communication with humans (Jorente; Padua; Nakano, 2019).

The articulation of DC with ID is part of the planning that should be oriented towards digital information organization and its presentation, especially when such information is attributed to various subjects, simultaneously and ubiquitously, in the digital environments on the Web. Much can be thought through the convergence of DC with ID for a digital collection from the perspective of information access and sharing (Chart 1). At the intersection between professionals and community, the possibilities for the visitor to create their collections, make comments, label digital objects, share on their social networks, among other activities that develop characteristics of interaction with collections and museums are encouraging (Padua; Jorente; Semedo, 2019).

Chart 1 - Contributions of Information Design on digital environments through the highlighted actions of the Digital Curation.

Information Design Contributions (1) (2) (3) Applications/Deliverables/Products

Organizational and visual practices (Padua; Jorente; Semedo, 2019). Documentation with descriptive memorial to enhance and create contextualized visual solutions.

Form and content integrity in information creation and presentation (Padua; Checklist with description of interface structures and accessibility to Jorente; Semedo, 2019). informational subjects.

Interfaces with visual and informational connections (Padua; Jorente; Navigation options for different profiles (students, educators, explorers, Semedo, 2019). etc.) to promote better interaction in digital environments.

Presentations, contextualizations and interpretations through collections Dynamic presentation of simulacra of collections to conform different (Sayão, 2016). contents and promote interactivity.

Collections presented through multiple languages and for different Responsiveness and functionality in the multimedia presentation of supports (Padua; Jorente; Semedo, 2019). information focused on access and sharing.

Optimized interoperability for informational subjects (Jorente; Padua; Dialogical, convergent, conversational and clear interfaces to facilitate Nakano, 2019). navigation.

Convergences between media and associated environmentsforinformation Digital strategies that promote interactive experiences between access and sharing. digital and physical. Integrative hypermedia platforms and resources to improve relationships.

Collaborative and cooperative space for education and scientific research List of options for collaboration and dialogue between curators and (Sayão, 2016). stakeholders, in an actively pedagogical way by converging practices and content.

Integration and interactivity to potential groups of netizens beyond the Tutorials and resources for exploring information sources and stakeholders. hyperlinks for the organization and presentation of simulacra of collections to optimize access, interaction and information retrieval.

Collections created by netizens themselves (Padua; Jorente; Semedo, 2019). Available resources and functions (comments, tags, share, like, among others), to promote conversation from the simulacra of collections.

Collective activity to encourage interpretations, classifications and Conversation-promoting features, such as creating profiles and other categorizations as strategic resources. actions to foster relationship with the institution.

Source: Prepared by the author (2021).

Note: Iterative actions highlighted from the DC: (1) description and representation information; (2) community watch and participation; (3) access and sharing.

From the point of view of museum institutions, using such attributes and resources to improve their digital environment with a view to fostering communication strategies related to their collections, promoting convergence with other online channels and optimizing visibility is vital.

\section{Final Considerations}

This study considers that, although most women's museums have digital environments, the number of collections available online is relatively low, as previously described. The DC planning of the actions and the ID 
resources can encourage such collections to grow in the panorama of the Web with the differential of the collective and horizontal knowledge construction from internauts' collaboration and interaction for the creation of new content.

In addition, when analyzing the themes approached in the Patrimonio en Femenino catalogs, the numerous issues that can be developed if worked in the domain of the association of these collections are noted. Technologies are considered to favor information access and sharing, expanding the dimensions of women's museums and providing much needed social dialogues. The multiplicity of women's museums around the world contributes to the preservation of women's memories in different cultures and societies. Extending them to digit-virtual museums can result in initiatives that go beyond physical boundaries and project in a decentralized manner.

Thus, the methodology used to contextualize DC and ID in the area of IS with an emphasis on both actions - in community watch and participation and in information access and sharing - it was possible to identify contributions from the articulation of the areas for the development of projects within the scope of women's museums digital collections. With community watch and participation, this study proposes the construction and creation of digital and informational environments that work as a two-way path, that is, that the resources and tools offered for the community of interest can be parameters for information professionals' practices and techniques.

Aspects related to the interoperability of languages and systems are also discussed in the scope of the DC and ID to organize and present the information in a clear and functional way. It is important to highlight that both iterative processes are subject to readjustments, as methodologically, they work in a cyclic way from the laboratorial experimentation that generates products in perpetual beta. In other words, they are procedures that need constant reassessment to reach effective solutions to the problems that may arise.

The use of ICT and DC actions from the perspective of ID with the insertion of women's museums digital collections can be developed and executed from the understanding of the complexity of each of the areas as subsystems of a mosaic culture characteristic of postmodernity.

\section{Acknowledgments}

Translation of articles or book chapters, by PROEX Agreement No. 565/2017, Graduate Program in Information Science, Universidade Estadual Paulista (UNESP).

\section{Contributors}

M. J. V. JORENTE was responsible for the study conception and design, writing, review and approval of the final version of the manuscript. S. C. SILVA was responsible for the literature review, analyze and writing of the manuscript. M. C. PADUA was responsible for the review and approval of the final version of the manuscript.

\section{References}

Abbott, D. What is Digital Curation? DCC Briefing Papers: introduction to curation. Edinburgh: JISC, 2008. p. 1-3, Available from: https://www.dcc.ac.uk/sites/default/files/ documents/resource/briefing-papers/what-is-digitalcuration.pdf. Cited: Nov. 12, 2020.

Araújo, C. A. A. O que é ciência da informação. Belo Horizonte: KMA, 2018.

Beagrie, N. The digital curation centre. Learned Publishing, v. 17, n. 1, p. 7-9, 2004. Available from: https://onlinelibrary.wiley.com/ doi/epdf/10.1087/095315104322710197. Cited: Nov. 13, 2020.
Chizzotti, A. A pesquisa qualitativa em ciências humanas e sociais: evolução e desafios. Revista Portuguesa de Educação, v. 16, n. 2, p. 221-236, 2003. Disponível em: https://www.redalyc. org/articulo.oa?id=37416210. Acesso em: 13 ago. 2020.

Digital Curation Centre. History of the DCC. Edinburgh: DCC, 2020a. Available from: https://www.dcc.ac.uk/about/historydcc. Cited: Nov. 12, 2020.

Digital Curation Centre. What is digital curation? Edinburgh: DCC, 2020b. Available from: https://www.dcc.ac.uk/about/ digital-curation. Cited: Nov. 12, 2020. 
Flick, U. Introdução à pesquisa qualitativa. Porto Alegre: Artmed, 2009. Disponível em: http://www2.fct.unesp.br/docentes/ geo/necio_turra/PPGG\%20-\%20PESQUISA\%20QUALI\%20 PARA\%20GEOGRAFIA/flick\%20-\%20introducao\%20a\%20 pesq\%20quali.pdf. Acesso em: 20 ago. 2020.

Frascara, J. What's information design. In: Frascara, J. (ed). Information design as principled action: making information accessible, relevant, understandable, and usable. Illinois: Common Ground Publishing LLC, 2015. p. 5-56.

Garrido; R. C.; Gómez, A. N. Género em red: seis años de Patrimonio em Femenino. In: Garrido, R. C.; Suela, M. G.; Gómez, A. N. (coord.). La memoria feminina: mujeres em la historia, historia de las mujeres. Espanha: Iberomuseos, 2016. p. 79-86. Disponible en: http://www.ibermuseos.org/wpcontent/uploads/2018/10/memoria-feminina-es.pdf. Acceso en: 15 jan. 2021.

Gil, A. C. Métodos e técnicas de pesquisa social. 6a ed. São Paulo: Atlas, 2008.

Godinho, T. Mulheres brasileiras: reiventando a vida, a história, a cultura. In: Garrido, R. C.; Suela, M. G.; Gómez, A. N. (coord.). La memoria feminina: mujeres em la historia, historia de las mujeres. Espanha: Iberomuseos, 2016. p. 37-44. Disponible en: http://www.ibermuseos.org/wp-content/uploads/2018/10/ memoria-feminina-es.pdf. Acceso en: 15 jan. 2021.

Higgins, S. Digital Curation: the new emergence discipline. The International Journal of Digital Curation, v. 6, n. 2, p. 78-88, 2011. Available from: http://www.ijdc.net/index.php/ijdc/ article/view/184. Cited: Dec. 10, 2020.

Higgins, S. The DCC curation lifecycle model. The International Journal of Digital Curation, v. 3, n. 1, p. 134-140, 2008. Available from: http://www.ijdc.net/article/view/69/48. Cited: Nov. 12, 2020.

Horn, R. E. Information design: emergence of a new profession. In: Jacobson, R. Information design. Cambridge: MIT Press, 1999. p. 15-34. Available from: https://epdf.pub/informationdesign.html. Cited: Jun. 16, 2020.

International Association of Women's Museums. The History of IAWM. Merano: IAWM, 2020. Available from: https://iawm. international. Cited: Jan. 12, 2021.

International Association of Women's Museums. Monitoring by the International Association of Women's Museums. Merano: IAWM, 2019. Available from: https://iawm.international/wpcontent/uploads/2019/10/2019-10-IAWM-List-of-Museumsand-Initiatives.pdf. Cited: Jan. 10, 2021.

International Association of Women's Museums. Welcome to our new member: MIMA Museu Internacional da Mulher. Merano: IAWM, 2019. Available from: https://iawm.international/?p=2428. Cited: Set. 21, 2021.

International Institute for Information Design. idX Information Design Core Competencies: what information designers know and can do. Austria: IIID, 2007. Available from: https://www. iiid.net/idx-information-design-core-competencies/. Cited: Jan. $12,2021$.

Jorente, M. J. V. (org.). Tecnologias e design da informação: interdisciplinaridades e novas perspectivas para a Ciência da Informação. Bauru: Canal 6, 2015.

Jorente, M. J. V.; Padua, M. C.; Nakano, N. O Design da Informação como recurso interdisciplinar da curadoria digital em contextos complexos da Ciência da Informação. Perspectivas em Ciência da Informação, v. 33, n. 4, p. 35-58,
2019. Disponível em: http://portaldeperiodicos.eci.ufmg.br/ index.php/pci/article/view/3127. Acesso em: 15 jan. 2021.

Nakano, N. Princípios do design da informação na curadoria digital de ambientes virtuais de aprendizagem sob a perspectiva da ciência da informação. 2019. Tese (Doutorado em Ciência da Informação) - Universidade Estadual Paulista, Marília, 2019. Disponível em: https://repositorio.unesp.br/ handle/11449/181518. Acesso em: 10 dec. 2020.

Oliveira, J. A. D. B.; Jorente, M. J. V. Design da Informação e sua relevância para a ciência da informação. Encontros Bibli, v. 24, n. 54, p. 25-37, 2019. Disponível em: https://periodicos.ufsc. br/index.php/eb/article/view/1518-2924.2019v24n54p25. Acesso em: 15 jul. 2020.

Padua, M. C.; Jorente, M. J. V.; Semedo, A. Design da informação e ações comunicacionais em websites de museus. In: Congresso Internacional de Design da Informação; Congresso Nacional de Iniciação Científica em Design da Informação, 9., Belo Horizonte, 2019. Anais eletrônicos [...]. São Paulo: Blucher, 2019. p. 1604-1614. Disponível em: https://www.proceedings. blucher.com.br/article-details/design-da-informao-e-aescomunicacionais-em-websites-de-museus-33744. Acesso em: 12 jan. 2021.

Patrimonio en Femenino. Portada. Madrid: Ministerio de Cultura y Deporte, 2020. Disponible en: http://www. culturaydeporte.gob.es/cultura/areas/museos/mc/ceres/ catalogos/catalogos-tematicos/patrimoniofemenino/ presentacion/portada.html. Acceso en: 15 jan. 2021.

Pará (Estado). Ministério Público. MPPA participa de evento alusivo ao dia internacional da mulher, promovido pela SUDAM. Belém: SUDAM, 2017. Disponível em: https://www2.mppa. mp.br/sistemas/gcsubsites/upload/81/ATIVIDADE\%20 MARCO\%20TB.pdf. Disponível em: 15 jan. 2021.

Portugal, C. Linguagem contemporânea: teorias e práticas. Design, Art and Technology Journal, v. 5, n. 2, p. 25-38, 2020. Disponível em: https://datjournal.anhembi.br/dat/article/ view/190. Acesso em: 23 jan. 2021.

RFI convida Katia Canton. Por RFI Brasil. [S. I.: s. n.], 2019. 1 vídeo (7 min). Disponível em: https://www.youtube.com/ watch?v=b26g2gX9CAA\&feature=emb_logo. Acesso em: 14 jan. 2021.

Sabharwal, A. Digital curation in the digital humanities: preserving and promoting archival and special collections. Kidlington: Elsevier, 2015. Available from: https://www.elsevier. $\mathrm{com} /$ books/digital-curation-in-the-digital-humanities/ sabharwal/978-0-08-100143-1. Cited: Dec. 15, 2020.

Sayão, L. F. Digitalização de acervos culturais: reuso, curadoria e preservação. In: Seminário Serviços de Informação em Museus, 4., São Paulo, 2016. Anais eletrônicos [...]. São Paulo: [s. n.], 2016. Disponível em: https://www.researchgate.net/ publication/319403030_Digitalizacao_de_acervos_culturais_ reuso_curadoria_e_preservacao. Acesso em: 3 jan. 2021.

Triviños, A. N. S. Introdução à pesquisa em ciências sociais: a pesquisa qualitativa em educação. São Paulo: Atlas, 1987. Disponível em: https://hugoribeiro.com.br/biblioteca-digital/ Trivinos-Introducao-Pesquisa-em_Ciencias-Sociais.pdf. Acesso em: 13 ago. 2020.

Vaquinhas, I. Museus do feminino, museologia de género e o contributo da história. Midas: Museus e Estudos Interdisciplinares, n. 3, p. 1-15, 2014. Disponível em: https:// journals.openedition.org/midas/603. Acesso em: 15 jan. 2021. 